\title{
Revealing the Meaning of Price on Dead Statues in Toraja Culture South Sulawesi, Indonesia
}

\author{
NATALIA PARANOAN \\ Faculty of Economics and Business \\ Universitas Kristen Indonesia Paulus \\ Jalan Perintis Kemerdekaan Km 13 Daya Makassar, South Sulawesi \\ INDONESIA
}

\begin{abstract}
Various studies have shown that accounting and the environment always influence each other, and the most influencing factor is culture. Accounting, in this case, pricing, is influenced by the culture of the local community. One of the regions in Indonesia, namely Toraja, has a unique culture of making statues of the dead for noble families. This way of setting the price of cultural products has its meaning. The purpose of this study is to reveal the meaning of price on dead statues in Toraja culture. That is qualitative research with the interpretive paradigms and phenomenological methods used to determine the daily experiences of individuals or communities. Data obtained from five informants chosen were informants with adequate knowledge of Tau- tau prices. The results showed that the formulated selling price of the dead statue is part of accounting practices with the Toraja people's culture has a meaning material value, spiritual value, and prestige value.
\end{abstract}

Keywords: Dead statue, meaning, price, material value, spiritual value, prestige value.

Received: November 28, 2020. Revised: May 14, 2021. Accepted: May 31, 2021. Published: June 16, 2021.

\section{Introduction}

Accounting is a discipline that is currently experiencing significant development. The ancient time shows what humans have been recognized with accounting transactions even in a straightforward form. Accounting as a science or profession, carried out by humans as members of society in general, has a cultural background in which culture is very closely related to society [6], [15], [17]. Along with its development, several factors greatly influence accounting, namely culture, economy, law, social and political in the environment in which accounting is located. Various studies prove that culture is the most potent factor influencing a country's accounting system and also how individuals in that country use accounting information [4], [16], [23].

Accounting as part of social science has a strong interaction (influence each other) with the social environment of society so that it has a role in shaping reality in society. Society has complex social environment characteristics and differences so that it is open to the possibility that they have a different perspective on an object, including the concept of accounting [2], [22].

Culture also touches on the price aspect of society. Every human activity always in contact with a price. In the past, prices were reflected through barter transactions. When the barter system is no longer sufficient to meet the needs of human life, prices become a shift towards transactions that use money as a means of exchange [19], [13]. At present, humans exchange or measure the value of an item using money, and the term used is the price [1], [17], [20] \& [21]. Price is one of the success determinants because price determines how much benefit will be obtained from its sale of goods or services.

Pricing is one of the critical decisions. The price must be able to cover all costs, or even more, to make a profit. According to Kotler \&Amstrong [11], determining the selling price is a determining process of what a company will receive in selling its products. On the other hand, price is not only the selling price itself, which is formed by quantitative values, but also qualitative values play a role in their formation. 
Many kinds of research on selling prices have been carried out, including Benito [3] research which examines the use of demand forecasting techniques by retailers to support their decision making. Hinterhuber [80] research about customer value-based pricing and Hwang [4] examines a practical pricing framework in a competitive industry. However, research related to price and culture has not been done much. Amaliah, in [1], points that the reveal of cultural values behind the determination of selling price from Bali transmigrant communities in Indonesia. And the result showed that the determination of selling price by Bali transmigrant communities not only to get the profit but also contains the culture values of Tri Hita Karana, which reflects the values of the submission to the creator, environmental conservation, and mutual assistance.

This study examines the meaning of the price on a product of culture. In the cultural life of a society, pricing is one of the critical decisions. Related to price and culture, in the Toraja community, there is one cultural product that is a product or item that must be present in a traditional ceremony, namely a statue of the dead called Tautau in tribe language, which is a miniature of a deceased person. This statue is only made for nobles and has a high price.

The role of Tau-tau in the culture of the Toraja community is significant so that often the price factor becomes a secondary consideration. This statue place around the place where his body buried. Tau-tau statue, made as closely as possible to people who have died. In the past, for making Tau-Tau limbs separated from the body. For example, hands, feet and genitals. The rituals make by cutting one pig from each of these limbs as a condition. So, it will do for completing the ritual. The ancients community also believed that the spirits of the dead would enter Tau-tau and continue to live. But over the times, Tau-tau was only a wooden "doll" that was given clothes.

The Tau-Tau craftsmen, who are also profit-oriented, are inseparable from the problem of achieving profits and return on capital so that the Tau-tau handicraft makers set prices accordingly. The right price is the price under the quality of the product of an item, and the price can provide satisfaction to consumers.

From time to time, the statue of the dead or Tau-Tau constantly experiences changes and developments from various sides, including material, size, position, and character of equipment, resemblance, and even payment methods. In this study, the research problem is to uncover the meaning of price on the statue of the dead in Toraja culture. In comparison, the research aims to find out the meaning of Tau-tau prices in Toraja culture.

The contribution of this research is the theoretical benefit. It can add to the literature on the study of business and economics related to culture in revealing the meaning of the price of a cultural product. Practical benefits provide insight to related parties that people must know that pricing on cultural products is the desired cost and profit. Still, there is an inherent meaning in the product.

\subsection{Definition of Price}

Price is an important thing, where the price is a significant component of customer satisfaction, and product value is what consumers feel, so buyers help determine the product's value. Profit to be gained and survival is very much determined. However, the income they get and depends on how many products sold. Also, the company's profit and company's survival are determined by how much income they earn, which depends on how many products are sold [20].

The selling price is the amount of compensation (money or goods) needed to get a combination of goods or services by setting the product's price in the hope that the product is sold and may get the maximum profit. Kotler \&Amstrong [11] defines the selling price as the monetary amount charged by a business unit to the buyer or customer for the goods or services sold or delivered. Whereas Mulyadi [12] defines that in principle, the selling price must be able to cover the total costs plus a reasonable profit, or the selling price is equal to the production costs plus mark-ups.

From the above definition, that can be concluded by selling of price. The price is the number of costs incurred to produce an item or service, that the desired profit percentage. Therefore to achieve the desired profit, one of the ways to attract the constemer interest of consumers. It is determining the right price for products sold. 


\subsection{Pricing Method}

Generally, the selling price of standard products and services is determined by considering demand and supply, so the cost is not a determining price. Because by setting competitive selling prices it will be able to increase sales volume. Therefore the need to maintain a predetermined selling price.Because with high selling prices it will be able to influence product demand and sales.

Basically, under normal circumstances, the selling price of a product or service must cover the total complete costs associated with the product or service and generate the desired profit. Full costs represent the total sacrifice of resources to produce a product or service, so all of these sacrifices must be able to be covered by the revenue obtained from the sale of the product or service [20]. Plasman \&Tidermann [18] suggested that the determination of the selling price is: "The monetary amount charged by a business unit to the buyer or customer for the goods or services sold or delivered". The selling price determination policy is a statement of management's attitude towards setting the selling price of a product or service. The policy does not determine the selling price but sets factors that need to be considered the basic rules that need to be followed in determining the selling price.

\subsection{Toraja Culture}

Toraja is also called Tondok Lepongan Bulan Tana Matari Allo, which means around lands like the moon and the sun, which is located about $350 \mathrm{~km}$ from the city of Makassar, the capital of South Sulawesi Province. The Toraja tribe is one of the tribes that inhabit the mainland of South Sulawesi. Since a long time ago, the Toraja have embraced a belief called Aluk Todolo. In Toraja culture, the ritual of death is called Aluk Rambu Solo, and the ritual of thanksgiving and happiness is called AlukRambuTuka.

Taylor in [17] tries to rearrange the origin and evolution of religious experiences and beliefs. According to Taylor, the initial stage of religion is animistic belief: the belief that nature has a soul. That belief is fundamental and universal. That can explain of worship of the dead. The worship of ancestors or ancestors and also explains the origin of the gods. The Toraja people covers all aspects of human life, including worship of the spirits of the ancestors. According to AlukTodolo's belief, people die merely a change of status solely, from humans who live into spirits in the supernatural.

For the Toraja people, the ritual of death is an important social event that is attended by many people and lasts for several days. In this event, the symbols are full of meaning, including the statue of Tau-tau, which is worshipped by the local community through animal offerings and specific dances.

\section{Problem Formulation}

This research is qualitative, that connection with the objectives to be achieved, namely to uncover the meaning of the selling price on the statue of the dead in the Toraja Culture. This study uses an interpretive paradigm with a phenomenological method. The interpretive paradigm focuses attention on the search for meaning for the experience of individuals or communities in their daily lives. Phenomenology is considered appropriate in this research. Analysis of individual consciousness is the focus of analysis in transcendental phenomenology that was sparked by Husserl [10], [14]. The emphasis of phenomenology leads to subjective experiences of the various characteristics. So, the subjects encountered and the reality of the world because humans have an awareness of that reality, making phenomenology have the ability to understand the existence of the world that appears to others. That is in line with the purpose of this study. That is trying to understand the values that shape the selling price concept that has its distinctiveness by the social and cultural contexts prevailing in the craftsmen of Tautau in Toraja.

On the other hand, the reason for using phenomenology in this study. To find the meaning of prices is aimed at the discovery of nature behind attitudes and actions by informants in setting prices. As expressed by [10], one of the focuses of phenomenology is based on vision through exploration by seeing, hearing, and feeling the reality related to the price. The appearance was found through Hussein's phenomenology procedures, namely noema, epoche, noesis, intentional analysis, and eidetic reduction. That leads the researcher to dig deeper into the awareness possessed by informants in setting the selling price practised by craftsmen in TanaToraja. 


\subsection{Research Informant}

The selection of informants is made purposively. First, the subject has been quite long and intensively integrated with the activities that are the target of research. The subject is not just knowing and can provide information but also has lived it seriously.

This study examines the meaning of the price of Tau-Tau. The researcher chooses the correct informant, the Tau-Tau sculptor, in two different places, Torajacommunity leaders, academics and service users. In this case, selected informants are informants who know about the problem being investigated, about the meaning of Tau-tau prices.

Table 1

List of Informants

\begin{tabular}{|c|c|}
\hline Name (Initial) & Profession \\
\hline NN & Tau-tau sculptor \\
\hline MS & Tau-tau craftsman \\
\hline TP & Customary leader \\
\hline SP & Lecturer in cultural \\
\hline SS & Customer \\
\hline
\end{tabular}

\subsection{Data Collection Technique}

Data on the meaning of the price is the statue of the dead or Tau-tau. That is obtained from interviews in the form of informants' answers. The questions raised by researchers through several questions. It flows just like that and is done face-toface with the informant. The answer data is presented in the form of an excerpt from the interview. The excerpt from the interview presents the respondent's answer regarding the statue of the dead or Tau-tau to answer the formulation of the problem that is the main focus of the study.

\subsection{Data Analysis Technique}

There are analyzing the data, namely knowing to price and revealing the meaning of Tautau prices in Toraja culture. That is to see the pricing of Tau-tau and the meaning of Tau-tau prices. So, the information about Toraja culture of Tau-tau can be understood.

Related to the use of phenomenology as a method in this study, the stages of analysis carried out are the noema, epoche, noesis, intention analysis, and eidetic reduction. These stages are key concepts of phenomenology. Phenomenon analysis begins with the stage of identifying noema (textural analysis). Based on the identification of the noema, researchers conducted bracketing of the findings captured in other textures under the texture (in other textures under the texture (structural analysis) to obtain deeper meaning or meaning [5], [10]. The tradition of phenomenology seeks to describe the phenomenon of daily life experienced. A community about the self-concept of informants according to their views. In principle, phenomenology Husserl emphasizes the original source of the subject's self and awareness to possess a subjective world about the meaning of life experience several people.

\section{Problem Solution}

The majority of the Toraja tribe embraced Christianity, while some embraced Islam and the animistic belief known as Aluk Todolo. The Toraja are famous for funeral rites, traditional house (Tongkonan), and wood carvings. Funeral rites in Toraja are significant social events, attended by hundreds to thousands of people, and last for several days. In this funeral service, a sculpture that resembles the dead is made, containing threedimensional photographs. peoples, said:

$\mathrm{TP}$, one of the leaders of indigenous

"The statue that was made was a photo of the person who died because there were no cameras, so sculptures were made in ancient times. Today even though there is a sculpture camera still made as part of proper equipment. "

Every society has rules that apply in its community environment and customs. All of the citizens must obey. For example, a high-level Rambu Solo ceremony (for high aristocrats) must present Tau-Tau in the process.

SP one of the academics revealed that:

"The rules of each customary area are different. Each customary area has its own rules, but the substance remains the same. Tau-Tau has to be in a funeral ceremony because it is an obligation. " 


\subsection{The Symbolic Meaning of Tau-tau in Toraja Culture}

At the present time, the forms of Tau-tau are very diverse. The Toraja aristocracy interpreted Tau-tau as a statue depicting someone, so the family ordered Tau-tau as a self-portrait of a family member of a sculpture artist. Tau-tau makes from jackfruit wood. People believed in the past that the sap of white jackfruit wood is the blood of a god. The Toraja aristocrats are considered incarnations of god. But today, because jackfruit wood is solid and durable and the colour is like human skin use today.

According to NN, a sculptor from the Londa area:

"Nowadays, people make Tau-tau from jackfruit wood because jackfruit wood is more potent than it is, the longer the colour of jackfruit wood almost resembles the colour of human skin. The white jackfruit sap is a symbol of royal blood."

At present, almost all of the Tau-tau make not based on aluk in meaning, there is no worship and rituals anymore, and they are no longer considering spirit incarnations. However, the Toraja people still maintain their traditions from generation to generation. It is because they consider it to be an ancestral inheritance that must be preserved its preservation and respect for its ancestors [7].

Tau-tau men have characteristics such as a relatively broad chin. Tau-tau clothing resembling male Toraja clothing in general (during Rambu Solo ceremony) wearing clothes resembling a coat, a headband called $p a^{\prime}$ rope, pants. Those are only up to the knee are called seppatallubuku and sash in the form of a sarong and are generally white. Tau-tau women have characteristics such as a somewhat oval chin, headgear called sarong made of bamboo cushions, shaped like an umbrella, clothes worn are Toraja traditional clothes. That wear unique sarong from woven fabrics and wear accessories [7].

According to SP:

"The accessories used by Tau-tau are accessories that look like when the person lives starting from clothes, necklaces, bracelets, and others. In the past, these accessories make from gold or expensive beads. But now, it is no longer used. It will use imitation or imitation assorts.

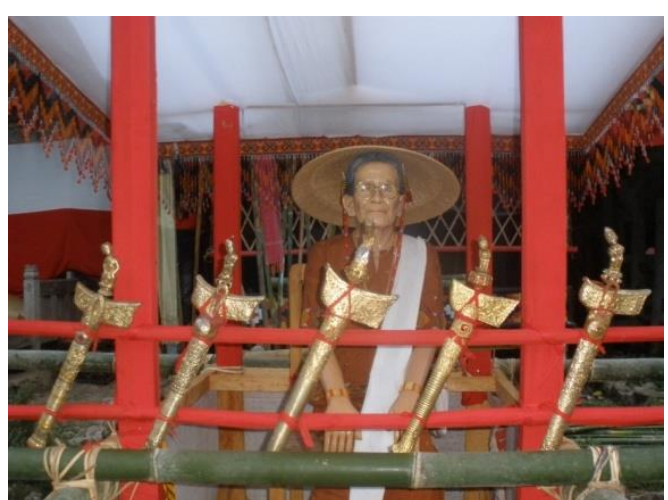

Figure 1. Tau-tau (Statue of the dead)

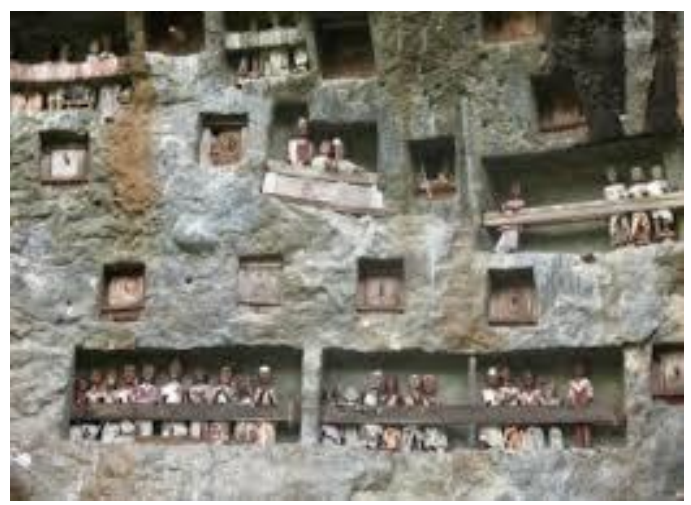

Figure 2. Hanging Graves with Tau-tau

\subsection{Pricing Tau-tau}

Determining the right selling price is very important because it relates to the amount of profit obtained. Maximum profitability is one of the target sellers. The process of determining the selling price of Tau-tau is quite simple. The sculptor only uses the estimated costs and desired profits. The desired profit is the skill of the sculptor. The sculptor buys all the raw materials for his production needs. Then he estimates the labor cost and other costs, and then he determines the desired profit.

In fact, in determining the selling price the sculptors do not have a specific method. The TauTau sculptors set a higher price because besides the sculptor's expertise, the manufacturing is complicated and requires a long time, and there is a spiritual value that makes Tau-Tau have a high price.

Based on the study results, the price set by one of the informants or the sculptor was IDR $25,000,000$ - IDR 30,000,000, depending on the size of Tau-tau and raw materials. If the price of wood rises, the price of Tau-Tau will also increase. Tautau sculptors do not use very detailed calculations to set price. 
According to MS:

"Costs incurred to make one or more usually are around IDR 7,500,000 include the cost of materials, food allowance, cigarettes, and salaries for other workers. I do not calculate in detail all the costs incurred. If the money from my pocket runs out or decreases, that is the expenditure for that day, but the expenditure does not exceed the amount of IDR 7,500,000 for one piece of Tau-tau"

The following will detail the use of fees for Tau-tau, although this calculation is an estimate because the makers of Tau-tau do not calculate in detail:

Table 2

The Cost of Making 1 Piece of Tau-tau

\begin{tabular}{|c|c|c|}
\hline No & Description & Amount (IDR) \\
\hline 1. & $\begin{array}{l}\text { Cost of raw material: } \\
\text { Wood, paint, glue }\end{array}$ & 3.800 .000 \\
\hline 2. & $\begin{array}{c}\text { Cost of direct labor 2 pax @ IDR } \\
500.000\end{array}$ & 1.000 .000 \\
\hline 3. & $\begin{array}{l}\text { Cost of consumption. Food, and } \\
\text { cigarette. }\end{array}$ & 2.500 .000 \\
\hline & Amount & 7.300 .000 \\
\hline
\end{tabular}

From table 2 above, it can be seen that the total cost incurred by a tau-tau sculptor is IDR 7,300,000. The statue was then sold for IDR 25,000,000 - IDR $30,000,000$. Then the difference from this amount is profit.

On the other hand, the price set by other informants in the Londa area is IDR 30,000,000 until IDR 40,000,000. Pricing depends on the size of the Tau-Tau, the price of the material, and family considerations. If the Tau-tau customer is a family of Tau-tau sculptors, the price can be lower around IDR 25,000,000. Likewise with the Tau-tau sculptors in the Londa area do not use very detailed calculations to set prices. According to NN:

"I only counted the cost of materials and money for food and cigarettes that I spent about IDR 6,000,000, but if it takes up to 3 (three) months to spend it could increase again, but I do not use members in making Tau-tau because not everyone can do it."

The Tau-Tau sculptors set a higher price because it makes it complicated and requires a long time even more careful in making, and with the spiritual value that supports Tau-tau has a high price.

\subsection{The Price of Tau-tau}

During this time, the concept of selling prices tends to only focus on profit figures as the ultimate goal. Determining the selling prices that rely on the achievement of profits only in the form of material realized or not can direct the culprit to unethical behavior. If we look further, actually, the definition of the selling price goes beyond mere costs and the achievement of material profits. The selling price is not only formed by the elements of costs and profit as contained in modern accounting. The selling price itself not only formed by quantitative values but qualitative values.

In making Tau-tau, it is inseparable from the price that forms it. That was revealed through interviews conducted by the author on who makes the Tau-tau. Toraja cultural tradition carries out, namely the funeral ceremony or Rambu Solo, which uses Tautau as one of the symbols displayed during the funeral service in the form of a high level of funeral service by cutting 24 or more buffaloes.

\section{According to SP:}

"Likewise with nobles if the buffalo pieces are insufficient or take the Rambu Solo package they cannot make Tau-Tau because they must meet the criteria according to the rules of the customary area where he is"

Based on the research results from two places of Tau-tau manufacture which has a difference in the time required to make. The time used in making Tau-tau in Londa reaches 1 (one) month, even up to 3 (three) months.

\section{According to NN:}

"The 3 (three) months at the longest depends on my mood, but the fastest is 1 (one) month, so people who come to order have come long before the due date and bring photos because the processing takes up months."

Then based on the results of research on other informants (MS), have a processing time of two weeks - one month. When Tau-tau is ordering, the person who ordered must bring a photo of the person who has died or will be made one Tau-tau. The photo will make it easier for Tau-Tau makers to make the Tau-Tau. Even though the Tau-tau customers are family members or people they know, they must bring photos of people who have died because of the difficulty, according to the sculptors, as part of the face. 
According to MS:

"Even though, we know or even our families who ordered. We still need to have photos because we hope the results will be the same as those in the photos if they have been made. We want to see how the shape of the face or signs are different from the face of the person, because that the most difficult part is the face".

\section{According to NN:}

"The price of Tau-Tau is very high. It is because of difficulty level and timeconsuming work. We also have to make sure that the Tau-tau is similar to the original picture of the dead people so that we do not get the wrong carving because we can lose if we carve. The price, I think that's reasonable because besides being difficult, in Toraja, it is still rare to make Tau-tau, there are only about seven people who actively make Tau-tau, but only a few are known to people. The price is also high (expensive), and Toraja people also do not question the price if necessary for the nobles the Rambu Solo ceremony. "

Although making Tau-tau is no longer as complex as in the past, which has to go through various customary processions, expensive raw materials, and complicated quality, which affects prices. Besides, the customary rules that require tautau to exist at the time of the death ceremony make this product still exist.

Nowadays, people who order Tau-tau are not only aristocrats, even though this violates customs. According to MS:

"If someone comes to order, sometimes we don't know if that person is from a noble class or not. The point is that those who come to order must be nobles, and we only make the order, but if there are lower-class people who order the statue, people like that don't understand the customs."

Based on interviews with the informants, the selling price set by the Tau-Tau sculptors has a high enough profit for 1 (one) Tau-tau, which reaches millions of rupiah. The price of Tau-tau that is formed contains values, namely:

\section{a. The Material Value}

Understanding the price concept that has been rife implemented so far comes from the motivation of gaining profits alone. The only purpose for which price-fixing is carried out is solely oriented, that is, money. This thinking is certainly based on the understanding that only the figures contained in costs and profits alone are reasonable measures that can be used in shaping prices. Likewise, the reality happened to the Tau-tau sculptors in Toraja. Even though they never accurately recorded every income or expense in making Tau-Tau. Regardless of the amount, profit remains the goal because no one wants loss.

According to MS:

"The benefits we get for one Tau-Tau are sufficient for daily expenses and savings, although most customers order in May to December, so we must be good at managing finances."

\section{According to NN:}

"The benefit I get for one Tau-Tau is enough for daily expenses and as savings, even though the price given is usually lower bargaining by the family. "

The sculptors never accurately recorded how much money was spent on making tautau. When the production of Tau-tau is completed and paid for, then they feel that they will get a profit from their work.

\section{According to MS:}

"I never record income to find out the benefits that I get, I just calculate and deduct it with costs, then from the profits to support the family and the rest as capital for making the next Tau-tau."

Based on the research results, the informants that the benefits or results obtained can meet the family's needs, savings, and capital for making the next Tau-tau.

Pricing or other than cost considerations, there is also a family price. The family price is set lower than the available price.

According to $\mathrm{NN}$ :

"If a family comes to order, the price will be lower, but the matter of the method or method of work and the results remain the same as ordinary people who come to order only a different price because of the family." 


\section{b. The Spiritual Value}

Based on the study results, service users sometimes do not consider the price set by the sculptor. The similarity of the Tau-tau is the primary consideration for deciding which carver will do the tau-tau. Tau-tau must be present in a high-level solo sign ceremony because it contains spiritual values for the Toraja community, especially for the family of the dead. That is what causes the sculptors to increase the price of knowing because of spiritual value freely.

According to SS:

"For us, the price does not matter. The important thing is the face must be as similar as possible. Therefore we usually use the services of a sculptor who is also our family because he knows the deceased well."

Toraja people always obey the rules that must be obeyed, like the obligations set by the adat council. Toraja people are known as people who have always maintained their cultural traditions for generations. The emergence of various forms. Forms of the present Tau-tau, which is an adjustment, the combination of the values of the old tradition or ancestor religion with the new tradition, is inseparable from an inauguration effort and the strengthening of the social status that the highranking Toraja aristocracy wants to show. That was especially done by high aristocrats who did not want to lose social stratification as the most honored or dignified symbol in Toraja society.

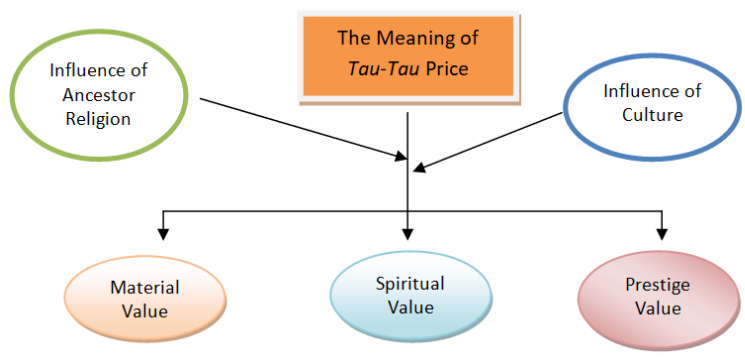

Figure 3.The Meaning of Tau-Tau Price

\section{c. The Prestige Value}

Tau-tau cannot be separated from high prices and prices associated with prestige. Even though the price of Tau-tau is high (expensive), Toraja people still make the Tau-tau for the completeness of the death ceremony. It is a symbol that leads to nobility, such as ownership of property, for example, carved traditional house (Tongkonan), carved barn (Alangsura'). The aristocrats still maintain Tau-tau as belonging to his group, which distinguishes it from other ordinary people. The aristocrats are the highest in society who have a particular position and control customs in society [15]. A Spiritual value contained in Tau-tau, which Toraja people high obey. Tau-tau's makers, even though they set high prices, the buyer will still buy because for the nobility, Tau-tau is a symbol of recognition for those who come from high level social or symbol of one's nobility. Therefore the price of the Tau-tau statue, although high (expensive), is not a problem for the aristocracy because it is associated with prestige.

\section{Conclusion}

The selling price is the essential factor in deciding to buy a product. Human life is always in contact with the price. Prices touch well on corporate business practices, public sector entities, and even in individual or group social life. The reality that occurs is the understanding of the concept of the price that has been rife implemented so far from the motivation to obtain profits alone, but actually, prices are formed not only by mere material elements but also by non-material elements.

Accounting is one of the fields of science that is currently experiencing development. Numbers and counts know to account. Accounting is also related to culture. So, the price of Tau-tau in the context of Toraja culture. Tau-tau is the personification of the dead or statue intended for people who have died. Tau-tau contains a value where everyone uses symbols in the Rambu Solo ceremony or makes a statue for their ancestors must be from the high aristocratic group who are community leaders.

Tau-tau has a high price because of the various values contained therein, namely: 1). 
material value, which is a predetermined price that is formed through the figures contained in the various costs incurred plus the expected profit. Price has the advantage that includes meeting the family's needs and as capital used in making the next TauTau. 2) Spiritual Value, which is the value of Tautau as a complement to the death ceremony meant as a tribute to the noble/deceased person so that the Tau-Tau carvers have a high enough profit for 1 (one) piece of Tau-Tau. 3). Prestige/value is a symbol that leads to noble groups such as ownership of property, carved traditional house or tongkonan (Banuasura), carved barn (Alangsura'), and Tau-tau at the highest level of death ceremony. The aristocrats still maintain Tau-tau as belonging to his group, which distinguishes it from other ordinary people. Therefore the high price of Tau-tau is not a problem for the aristocracy. Tau-tau is one of the symbols that they are come from the noble class and do not want to lose their identity. The royalty, where the aristocrats are the highest in society who have a particular position and control customs in society, affects the local community's economy.

\section{References:}

[1] Amaliah, T.H. 2016. Nilai-Nilai Budaya Tri Hita Karana dalam Penetapan Harga Jual [Tri Hita Karana Cultural Values in Setting Selling Prices]. Jurnal Akuntansi Multiparadigma. 7 (2), 189-206.

[2] Belkaoui, A.R. 2000. Accounting Theory.Forth Edition. Thomson Learning, London.

[3] Benito, Ó. G., M.P.M. Ruiz, and A.M. Descals. 2010. "Retail Pricing Decisions and Product Category Competitive Structure". Decision Support Systems, 49 (1), 110-119.

[4] Campoy-Mmuioz, P., Cardenete, M.M.A, \& Delgado, M.C. 2016. Assesing the Economic Impact of a Cultural Heritage Site Using Social Accounting Matrices: The Case of the Mosque-Catedral of Cordoba. Tourism Economics, 23 (4), 874-881.

[5] Creswell, 2007. Qualitative Inquiry \& Research Design.Second Edition. Sage Publication London, New Delhi.

[6] Darwis, N. \& R. Mulyani. 2012. Perspektif NilaiBudaya Masyarakat Bugis Dalam Penerapan Corporate Social Responsibility (CSR) Pada PT. Taspi Trading Coy di Makassar [The Perspective of Bugis Cultural
Values in the Implementation of Corporate Social Responsibility (CSR) at PT. Taspi Trading Coy in Makassar]. Thesis. Fakultas Ekonomi \& Bisnis. Universitas Hasanuddin.

[7] Datuan, Y. M. 2011. Makna Simbolik TauTau Dalam Sistem Stratifikasi Sosial Pada Pelaksanaan Upacara Rambu Solo' di Desa Leatung Kec.Sangalla' Utara Kab. Tana Toraja.[The Symbolic Meaning of Tau-Tau in the Social Stratification System for the Rambu Solo' Ceremony in Leatung Village, North Sangalla' District, Tana Toraja Regency]. Thesis. Fakultas Ilmu Sosial Dan Ilmu Politik. Universitas Hasanuddin.

[8] Hinterhuber, A. 2008. "Customer Value Based Pricing Strategies: Why Companies Resist". Journal of Business Strategy, 29 (4), 41-50.

[9 ] Hwang, B., J. Tsai, H.C. Yu, dan S.C. Chang. 2011. "An Effective Pricing Framework in A Competitive Industry: Management Processes and Implementation Guidelines." Journal of Revenue and Pricing Management, 10 (3), 31-243.

[10] Kamayanti, A. 2016. Metodologi Penelitian Kualitatif Akuntansi.[Qualitative Research Methodology in Accounting]. Yayasan Rumah Peneleh Jakarta.

[11] Kohler, P.\& G. Amstrong. 2014. Principles of Marketing, 12th Edition. Erlangga, Jakarta.

[12] Mulyadi. 2012. Sistem Perencanaan dan Pengendalian Manajemen. [Management Planning and Control System].SalembaEmpat. Jakarta

[13] Paranoan, N. \& Tikupasang, W. 2013. Traditional Accounting Practice in Toraja South Sulawesi. E-book. Reviving The Negledted Knowledge.

[14] Paranoan, N. 2015. Riset Non Positivistik Akuntansi Dalam Tiga Paradigma: Interpretif, Kritis dan Posmodernisme [Non-Positivistic Research in Accounting in Three Paradigms: Interpretive, Critical and Postmodernism ]. Jurnal Ilmiah Akuntansi dan Bisnis. 10,(1).

[15] Paranoan, N. \& Pasanda, E. 2017. Power Behind Pricing Practices Based on Torajanese Culture. Journal Research of Financial and Accounting (JRFA).Vol 8(6).

[16] Paranoan, N., Peleng, P.R., Tandirerung, C.J., \& Tandungan, E.S. 2018. Disclosing Professionalism Behavior of Internal Auditor in Preventing Fraud by Using The Local Culture Wisdom "Longko". Proceeding ICOI (International Conference of Organizational Innovation), Fukuoka University, Japan. 
[17] Paranoan, N., Peleng, P.R., Tandirerung, C.J., \&Tandungan, E.S. 2019. Fraud Prevention in Bourdieu Thoughts. Journal of Critical Reviews 6 (5), 46-50.

[18] Plassmann, F., \& Tiderman, T. N. 2011. Marginal Cost Pricing and Eminent Domain. Foundations and Trends in Microeconomics, $7(1)$, 1-110. http://dx.doi.org/10.1561/0700000050

[19] Snelgrove, T. 2012. Value Pricing When You Understand Your Customers: Total Cost of Ownership Past, Present And Future, Journal of Revenue and Pricing Management, 11 (2), 76-80.

[20] Sulpa, N. 2014. Proses Penentuan Harga Jual Pada Rumah Makan Citra Minang Di Makassar [The Process of Determining the Selling Price of the Citra Minang Restaurant in Makassar]. Thesis. Fakultas Ekonomi dan Bisnis. Universitas Hasanuddin.

[21] Stanley, C. 2017. Strategic Cost Management and Performance: The Case of Environmental Costs, Social and Environmental. Accountability Journal, 37 (2), 150-161.

[22] Suwardjono. 2014. Teori Akuntansi, Perekayasaan Pelaporan Keuangan [Accounting Theory, Financial Reporting Engineering]. 3 Edition, BPFE, Yogyakarta.

[23] Zaitul. 2018. Tinjauan Kritis Tentang Pengaruh Budaya Terhadap Sistem Akuntansi [Critical Review of the Culture Influence on the Accounting System]. Journal Fakultas Ekonomi. Universitas Bung Hatta, 27 (2), 125-131.

\section{Creative Commons Attribution License 4.0 (Attribution 4.0 International, CC BY 4.0)}

This article is published under the terms of the Creative Commons Attribution License 4.0

https://creativecommons.org/licenses/by/4.0/deed.en US 